\title{
Role of Ethrel in Manipulation of Sex Expression in Pistillate and Monoecious Lines of Castor (Ricinus communis L.) at Different Concentrations
}

\author{
P. Vema* and S. Narender Reddy \\ Department of Crop Physiology, College of Agriculture, PJTS Agricultural University, \\ Rajendranagar, Hyderabad -500 030, Telangana, India \\ *Corresponding author
}

\section{A B S T R A C T}

\begin{tabular}{|l|}
\hline Ke y w o r d s \\
Castor, Pistillate, \\
Monoecious, \\
Interspersed staminate \\
flowers (ISFs). \\
\hline Article Info \\
\hline $\begin{array}{l}\text { Accepted: } \\
\text { 15 September } 2017 \\
\text { Available Online: } \\
\text { 10 November } 2017\end{array}$ \\
\hline
\end{tabular}

Keywords

Castor, Pistillate,

Monoecious,

Interspersed staminate flowers (ISFs)

\section{Introduction}

Castor (Ricinus communis L.) is an important industrial and non-edible oil seed crop grown under varied climatic conditions including tropical, sub-tropical and temperate regions. The castor seed oil is unique in terms of its dominance of a single fatty acid- ricinoleic acid (85-95\%), Castor oil and its derivatives are being used in textiles, soaps, wetting agents, synthetic resins, cosmetics, nylon fibers, bullet-proof glass and as antifreeze for fuels and lubricants utilized in aircrafts and space rockets (Ogunniyi, 2006).

Castor is a sexually polymorphic species with different sex forms viz., monoecious, pistillate, sex revertants and pistillate with interspersed staminate flowers (ISFs). The most natural occurrence of annual and perennial castor is in the form of monoecious. The spike has basal $1 / 3^{\text {rd }}$ to $1 / 2$ male flowers while the top portion has female flowers. The pistillate spike occurs as a rare recessive mutant with the spike having female flowers throughout the spike. A variant of pistillate form with male flowers interspersed throughout the female flowers on the spike is termed as Interspersed Staminate Flowers (ISF). Sex expression in castor is highly influenced by environmental factors viz., high day temperature, photoperiod, fertility, age of 
the plant, nutrition, etc. (Shifriss, 1960; Zimmerman and Smith, 1966). Castor performs well at moderate temperature of 20$26^{\circ} \mathrm{C}$. Mean temperatures of $31-32^{\circ} \mathrm{C}$ promote ISF, while low temperature resulted in fully female racemes (Ankineedu and Rao, 1973). Low temperature $\left(<30^{\circ} \mathrm{C}\right)$ and higher nutrition promote female flowers and shift the balance towards femaleness on spike. High temperature $\left(>32^{\circ} \mathrm{C}\right)$, late order spikes and low nutrition promote male flowers on a spike (Lavanya, 2002).

The expression of environmentally sensitive ISFs plays a key role in maintenance of pistillate lines. The instability of pistillate lines due to occurrence of ISFs is causing a serious problem in maintaining the genetic purity of the seed. As the conventional methods being time consuming, keeping the above issues in view an attempt has been made to know the effect of ethrel in reducing or suppressing the production of ISF or male flowers and cause an increase in female tendency and seed yield. Enhanced flowering by ethylene in angiosperms is well documented and ethylene-releasing compounds have been applied to enhance flowering in agriculture plants (Abeles et al., 1992).

\section{Materials and Methods}

A field experiment was conducted during rabi, 2013 at College of Agriculture, Rajendranagar, Hyderabad. The experimental soil was sandy loam in texture. The experiment was laid out in randomized block design with 12 treatments and replicated thrice. The experiment consisted of one monoecious line DCS-107 and two pistillate lines i.e., M-574 and DPC-9. Ethrel at 100, 150 and 200 ppm concentrations and control (water spray) was sprayed at 15, 30, 45 and 60 DAS. When ethrel is applied in aqueous spray is actively taken up in transpiration stream and translocated to leaves and flowers. Based on the fact that ethrel disintegrates in plant tissues and is converted to ethylene with consequent biological effects indicates that exogenous ethrel-treated tissues produce plant responses similar to endogenous ethylene (Cooke and Randall, 1968; Morgan, 1969; Warner and Leopold, 1969). Data were collected on various parameters viz., number of Interspersed Staminate Flowers (ISFs) or male flowers per primary and secondary spikes, phenological parameters, yield and yield components.

\section{Results and Discussion}

The present study revealed a trend of decreasing number of ISF or male flowers per spike with increasing concentration of upto $200 \mathrm{ppm}$ concentration in both pistillate lines (M-574 \& DPC-9) and monoecious line (DCS-107). Ethrel sprays were found effective in increasing female tendency and supress the number of ISF or male flowers in castor was reported by Ramesh et al., (2000). Similar findings were also reported earlier by Gopala Krishna Murthy et al., (2003); Dhedhi et al., (2010) in castor. The reduced level of endogenous gibberellins and increased level of auxin after ethrel spray during initial stages may be probable reason for increased female flowers and decreased male flowers as reported by Rudinch et al., (1972).

\section{Number of Interspersed Staminate Flowers (ISFs) or male flowers in primary spike per plant}

The data on number of ISF or male flowers in primary order spikes under different treatments, genotypes and their interaction were found to be statistically significant and presented in Table 1. Among the genotypes the pistillate line M-574 recorded in less number of ISFs (5.74) while in monoecious line DCS-107 more number of male flowers 
(39.69) per primary spike was recorded. There was a significant impact on regulation of ISF or male flowers in primary spikes of three genotypes with different concentration of ethrel treatments. The minimum number of ISF or male flowers on primary spike per plant (13.23) was recorded with ethrel sprayed at $200 \mathrm{ppm}$, whereas highest number of ISF or male flowers on primary spike per plant (22.85) was recorded in control (water spray). Among the treatment combinations, in pistillate lines minimum number of ISF was recorded with ethrel sprayed at $200 \mathrm{ppm}$ in M-574 (3.13) and the highest number of ISF was recorded in DPC-9 (12.39) with water spray (control). Whereas, in case of monoecious line DCS-107 the minimum number male flowers (31.47) were observed when ethrel was sprayed at a concentration of $200 \mathrm{ppm}$ and the maximum number male flowers (48.13) on primary spike per plant were recorded in control (water spray).

A significant reduction of upto 34 percent in number of male flowers in monoecious variety DCS-107 was observed at 200 ppm ethrel concentration compared to control (48.13), indicated the scope of ethrel to maintain proper male: female ratio even in male lines and varieties of castor. Similar findings were also reported by (Mary Varkey et al., 1982; Ramesh et al., 2000 in castor and Gopala Krishna Murthy et al., 2003a in castor); (Karchi and Grovers, 1972; Sitaram et al., 1989 and Arora et al., 1989 in cucurbits.) that ethrel sprayed plants resulted in increased femaleness as compared to untreated plants.

Number of Interspersed Staminate Flowers (ISFs) or male flowers in secondary order spike per plant

The data on ISF or Male flowers on secondary spike were presented in Table 2 . Genotypes exhibited significant impact on number of ISF or Male flowers on secondary spikes of castor. Among the genotypes the minimum number of ISF or Male flowers on secondary spike was observed in M-574 (6.75) followed by DPC-9 (8.37) and DCS107 (22.92). The trend of decreasing number of ISF in secondary spike with increasing concentration of ethrel upto $200 \mathrm{ppm}$ is also observed in both pistillate lines DPC-9 \& M574. Similar trend was also observed in the monoecious variety DCS-107 with significant reduction of upto 14 to 27 percent (100 to 200 ppm) over control in number of male flowers on secondary spike. Among all the treatments ethrel at $200 \mathrm{ppm}$ recorded minimum number of ISF or Male flowers (10.09) followed by ethrel at $150 \mathrm{ppm}$ (11.77) and ethrel at 100 ppm (13.26). Control (water spray) recorded maximum number of ISF or Male flowers (15.58) as compared to ethrel treatments. Among the interactions effects, ethrel at 200 ppm on M-574 (4.20) recorded minimum number of ISF in DPC-9 (6.33) and DCS-107 (19.75 male flowers). While the maximum number of ISF or Male flowers on secondary spike were observed in control (water spray) on DCS-107 (27.20 Male flowers) followed by DPC-9 (10.60 ISFs) and M-574 (8.96 ISFs) (Fig. 1).

\section{Effective length of primary spike}

Treatments had significant impact on effective length of primary spike and were found to be statistically significant and the data presented in Table 3. Among the genotypes maximum length of primary spike was recorded in M-574 $(57.81 \mathrm{~cm})$ followed by DPC-9 $(52.70 \mathrm{~cm})$. Minimum spike length was recorded in DCS-107 $(40.50 \mathrm{~cm})$. Ethrel at $200 \mathrm{ppm}$ resulted in maximum effective spike length of primary spike $(53.36 \mathrm{~cm})$ followed by ethrel at $150 \mathrm{ppm}(51.21 \mathrm{~cm})$ and ethrel at $100 \mathrm{ppm}(49.30 \mathrm{~cm})$. Minimum length of effective spike $(47.48 \mathrm{~cm})$ was recorded in control. Spraying of ethrel might have coincided with active vegetative growth 
and rapid cell elongation and cell division in growing portion of the plant and later increase the uptake of nutrients and photosynthetic activity resulting in increased length of spike.
The results are in agreement with earlier reports of Mary Varkey et al., (1982) in castor; Sidhu et al., (1982) in musk melon; Arora et al., (1989) in pumpkin (Fig. 2).

Table.1 Effect of ethrel on number of ISF or male flowers in primary spike of castor

\begin{tabular}{|c|c|c|c|c|}
\hline & \multicolumn{3}{|c|}{ Genotypes (G) } & \multirow{2}{*}{ Mean } \\
\cline { 2 - 4 } Treatments (T) & M-574 & DPC-9 & DCS-I07 & 19.53 \\
\hline $\mathrm{T}_{1}$ - Ethrel @ 100 ppm & 6.33 & 9.33 & 42.93 & 16.77 \\
\hline $\mathrm{T}_{2}$ - Ethrel @ 150 ppm & 5.48 & 8.63 & 36.22 & 13.23 \\
\hline $\mathrm{T}_{3}$ - Ethrel @ 200 ppm & 3.13 & 5.08 & 31.47 & 22.85 \\
\hline $\mathrm{T}_{0}$ - Control (Water Spray) & 8.03 & 12.39 & 48.13 & \multicolumn{2}{|c|}{ T X G } \\
\hline Mean & 5.74 & 8.86 & 39.69 & \multicolumn{2}{c|}{0.48} \\
\hline & T & G & \multicolumn{2}{c|}{1.43} \\
\hline S.E $\mathbf{m} \pm$ & 0.28 & 0.24 & \multicolumn{3}{c}{} \\
\hline C.D $(\mathbf{0 . 0 5})$ & 0.82 & 0.71 & \multicolumn{3}{|c|}{} \\
\hline
\end{tabular}

Table.2 Effect of treatments on number of ISF or male flowers in secondary spike of castor

\begin{tabular}{|c|c|c|c|c|}
\hline \multirow{2}{*}{ Treatments (T) } & \multicolumn{3}{|c|}{ Genotypes (G) } & \multirow{2}{*}{ Mean } \\
\cline { 2 - 4 } & M-574 & DPC-9 & DCS-I07 & 13.26 \\
\hline $\mathrm{T}_{1}$ - Ethrel @ 100 ppm & 7.64 & 8.90 & 23.26 & 11.77 \\
\hline $\mathrm{T}_{2}$ - Ethrel @ 150 ppm & 6.20 & 7.66 & 21.46 & 10.09 \\
\hline $\mathrm{T}_{3}$ - Ethrel @ 200 ppm & 4.20 & 6.33 & 19.75 & 15.58 \\
\hline $\mathrm{T}_{0}$ - Control (Water Spray) & 8.96 & 10.60 & 27.20 & \\
\hline Mean & 6.75 & 8.37 & 22.92 & \multicolumn{3}{|c|}{ T X G } \\
\hline & T & G & \multicolumn{3}{|c|}{0.37} \\
\hline S.E m \pm & 0.21 & 0.18 & \multicolumn{2}{c|}{1.09} \\
\hline C.D $(\mathbf{0 . 0 5})$ & 0.63 & 0.54 & \multicolumn{2}{c}{} \\
\hline
\end{tabular}

Table.3 Effect of ethrel on effective length of primary spike in castor

\begin{tabular}{|c|c|c|c|c|}
\hline \multirow{2}{*}{ Treatments (T) } & \multicolumn{3}{|c|}{ Genotypes (G) } & \multirow{2}{*}{ Mean } \\
\cline { 2 - 4 } & M-574 & DPC-9 & $\begin{array}{c}\text { DCS- } \\
\text { I07 }\end{array}$ & \\
\hline $\mathrm{T}_{1}$ - Ethrel @ 100 ppm & 56.14 & 51.44 & 40.33 & 49.30 \\
\hline $\mathrm{T}_{2}$ - Ethrel @ 150 ppm & 58.10 & 53.74 & 41.80 & 51.21 \\
\hline $\mathrm{T}_{3}$ - Ethrel @ 200 ppm & 61.40 & 55.54 & 43.16 & 53.36 \\
\hline $\mathrm{T}_{0}$ - Control (Water Spray) & 55.60 & 50.10 & 36.73 & 47.48 \\
\hline Mean & 57.81 & 52.70 & 40.50 & \\
\hline & T & G & \multicolumn{2}{|c|}{ T X G } \\
\hline S.E m \pm & 0.28 & 0.24 & \multicolumn{2}{c|}{0.49} \\
\hline C.D (0.05) & 0.84 & 0.72 & \multicolumn{2}{c|}{ NS } \\
\hline
\end{tabular}


Table.4 Effect of ethrel on number of capsules in primary order spike of castor

\begin{tabular}{|c|c|c|c|c|}
\hline \multirow[b]{2}{*}{ Treatments $(\mathbf{T})$} & \multicolumn{3}{|c|}{ Genotypes (G) } & \multirow[b]{2}{*}{ Mean } \\
\hline & M-574 & DPC-9 & DCS-I07 & \\
\hline $\mathrm{T}_{1}$ - Ethrel @ 100 ppm & 53.05 & 56.00 & 49.30 & 52.78 \\
\hline $\mathrm{T}_{2}$ - Ethrel @ 150 ppm & 54.40 & 57.35 & 50.66 & 54.14 \\
\hline $\mathrm{T}_{3}$ - Ethrel @ 200 ppm & 57.20 & 60.63 & 53.86 & 57.23 \\
\hline $\mathrm{T}_{0}-$ Control (Water Spray) & 50.20 & 52.30 & 41.66 & 48.05 \\
\hline Mean & 53.71 & 56.57 & 48.87 & \\
\hline & $\mathbf{T}$ & $\mathbf{G}$ & \multicolumn{2}{|c|}{ T X G } \\
\hline S.E m \pm & 0.20 & 0.17 & \multicolumn{2}{|c|}{0.35} \\
\hline C.D (0.05) & 0.60 & 0.52 & \multicolumn{2}{|c|}{1.04} \\
\hline
\end{tabular}

Table.5 Effect of ethrel on 100- seed weight (g) in castor

\begin{tabular}{|c|c|c|c|c|}
\hline \multirow[b]{2}{*}{ Treatments $(\mathbf{T})$} & \multicolumn{3}{|c|}{ Genotypes (G) } & \multirow[b]{2}{*}{ Mean } \\
\hline & M-574 & DPC-9 & DCS-I07 & \\
\hline $\mathrm{T}_{1}$ - Ethrel@100 ppm & 27.66 & 28.60 & 29.13 & 28.46 \\
\hline $\mathrm{T}_{2}$ - Ethrel@150 ppm & 28.33 & 29.13 & 29.95 & 29.14 \\
\hline $\mathrm{T}_{3}$ - Ethrel@ 200 ppm & 30.14 & 29.82 & 31.73 & 30.65 \\
\hline $\mathrm{T}_{0}-$ Control (Water Spray) & 26.72 & 27.26 & 28.37 & 27.45 \\
\hline \multirow[t]{2}{*}{ Mean } & 28.28 & 28.70 & 29.80 & \\
\hline & $\mathbf{T}$ & $\mathbf{G}$ & \multicolumn{2}{|c|}{ TX G } \\
\hline S.E m \pm & 0.14 & 0.12 & \multicolumn{2}{|c|}{0.25} \\
\hline C.D (0.05) & 0.42 & 0.36 & \multicolumn{2}{|c|}{$\mathrm{NS}$} \\
\hline
\end{tabular}

Table.6 Effect of ethrel on Seed yield (g)/plant in castor

\begin{tabular}{|c|c|c|c|c|}
\hline \multirow[b]{2}{*}{ Treatments $(\mathbf{T})$} & \multicolumn{3}{|c|}{ Genotypes (G) } & \multirow[b]{2}{*}{ Mean } \\
\hline & M-574 & DPC-9 & DCS-I07 & \\
\hline $\mathrm{T}_{1}$ - Ethrel @ 100 ppm & 82.26 & 90.64 & 85.05 & 85.98 \\
\hline $\mathrm{T}_{2}$ - Ethrel @150 ppm & 83.82 & 90.88 & 86.19 & 86.96 \\
\hline $\mathrm{T}_{3}$ - Ethrel@200 ppm & 85.42 & 91.60 & 88.30 & 88.44 \\
\hline $\mathrm{T}_{0}$ - Control (Water Spray) & 79.95 & 88.97 & 80.97 & 83.29 \\
\hline \multirow[t]{2}{*}{ Mean } & 82.86 & 90.52 & 85.12 & \\
\hline & $\mathbf{T}$ & $\mathbf{G}$ & \multicolumn{2}{|c|}{ T X G } \\
\hline S.E m \pm & 0.23 & 0.20 & \multicolumn{2}{|c|}{0.41} \\
\hline C.D (0.05) & 0.69 & 0.60 & \multicolumn{2}{|c|}{1.20} \\
\hline
\end{tabular}


Fig.1 Effect of ethrel on number of ISF or male flowers in primary and secondary spike of castor
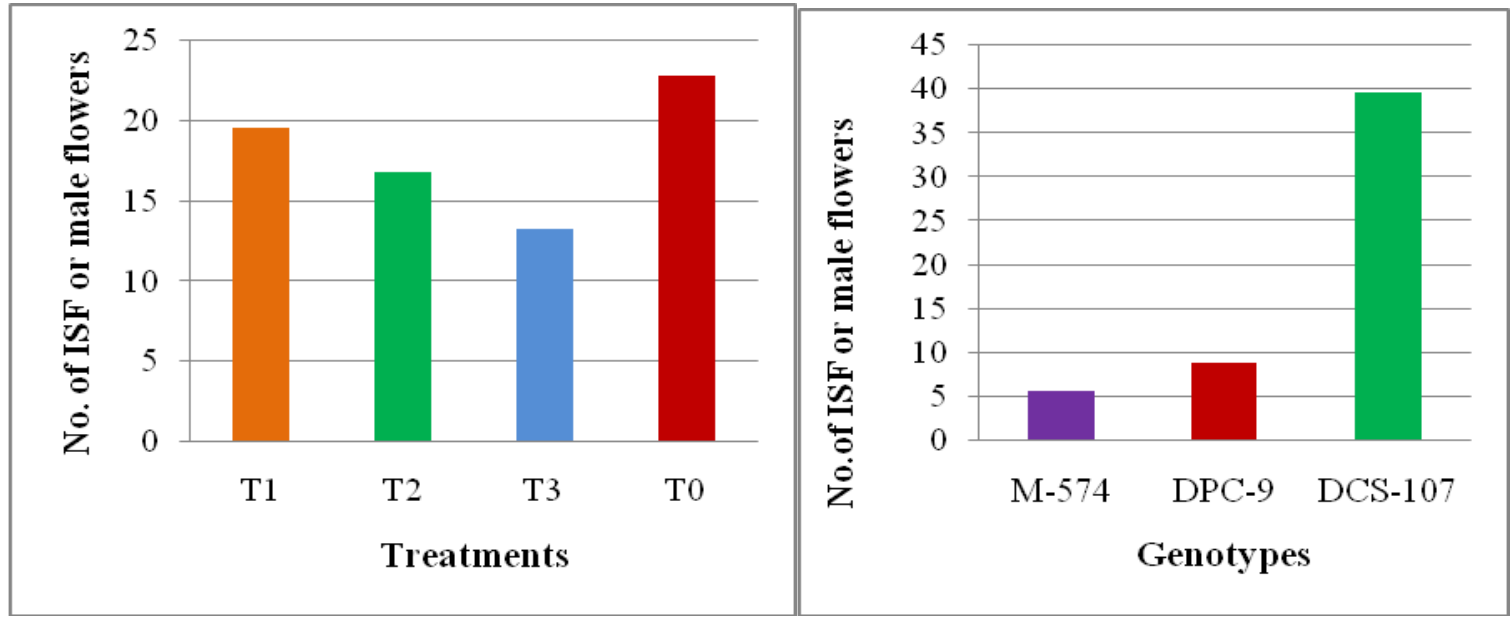

Fig.2 Effect of ethrel on effective spike length $(\mathrm{cm})$ in castor
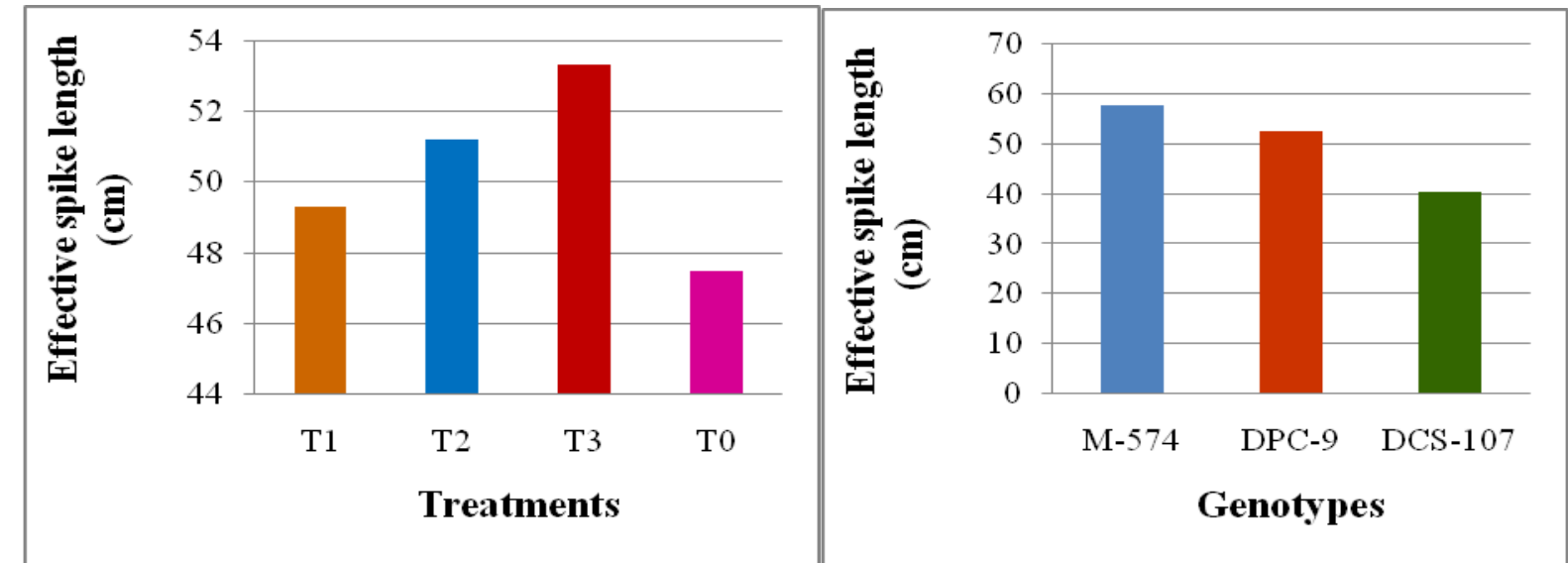

$\mathrm{T}_{1}-100$ ppm Ethrel

$\mathrm{T}_{3}-200$ ppm Ethrel

$\mathrm{T}_{2-} 150 \mathrm{ppm}$ Ethrel

$\mathrm{T}_{0^{-}}$Control (Water spray)

Fig.3 Effect of ethrel on number of capsules in primary spike of castor
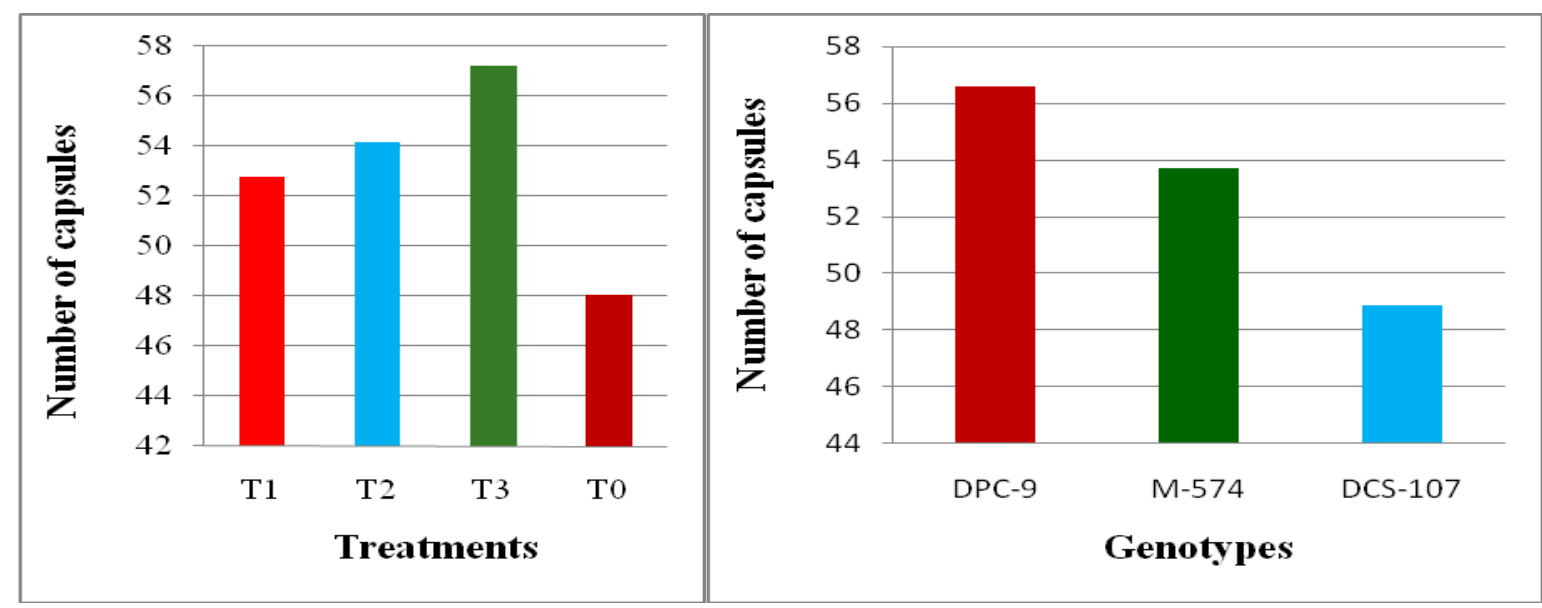
Fig.4 Effect of ethrel on 100- seed weight in castor

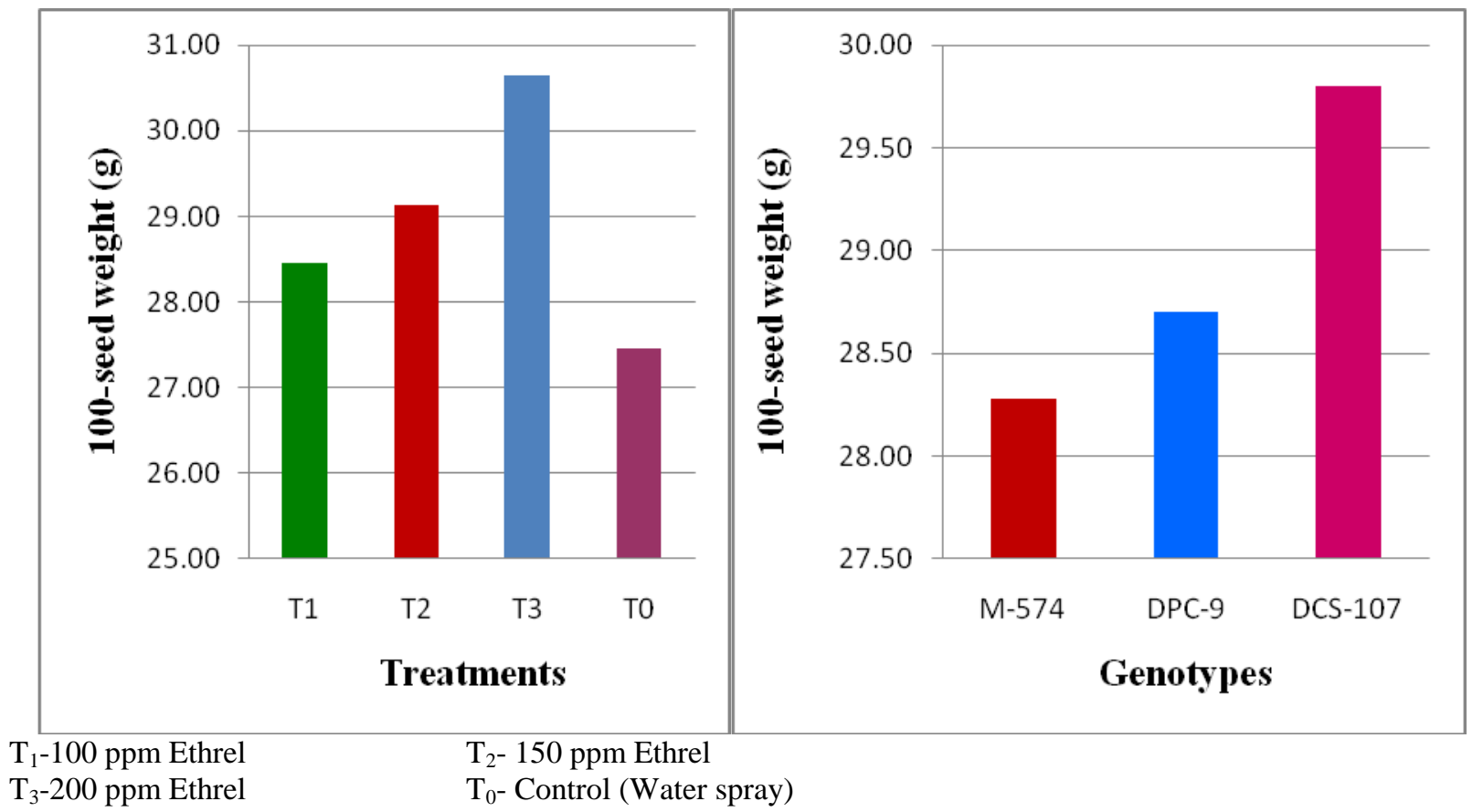

Fig.5 Effect of ethrel on seed yield (g) per plant

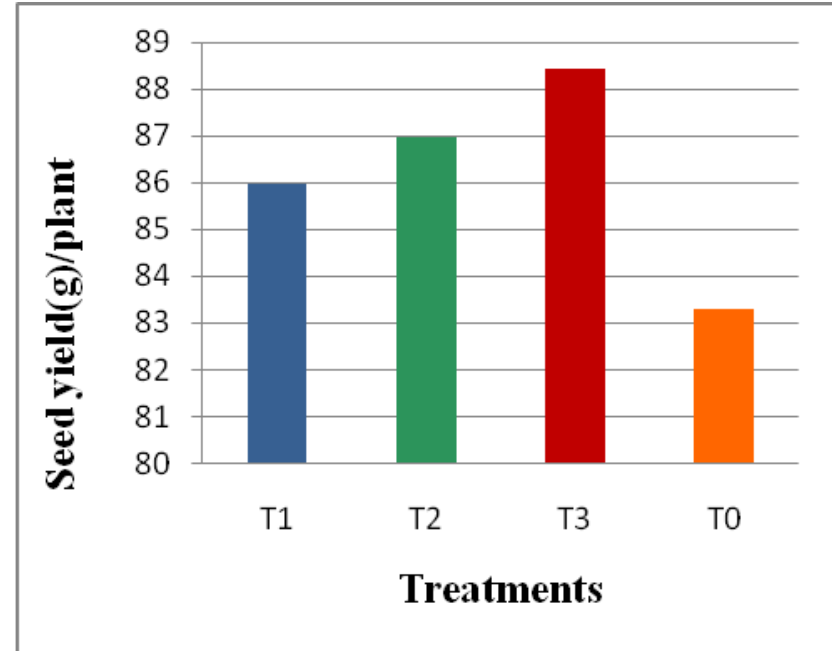

$\mathrm{T}_{1}-100$ ppm Ethrel $\mathrm{T}_{3}$-200 ppm Ethrel

$\mathrm{T}_{2^{-}} 150 \mathrm{ppm}$ Ethrel

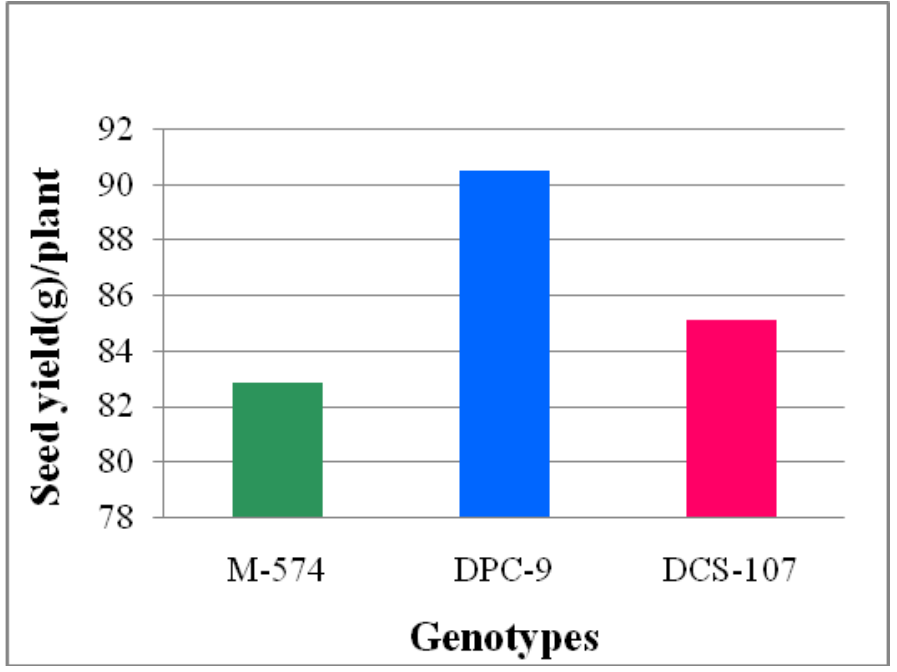

$\mathrm{T}_{0}$ - Control (Water spray)

\section{Number of capsules in primary spike}

In the present study, development of more number of capsules per primary spike is due to increased number of female flowers in primary spike. Ethrel sprays might have increased the endogenous auxin levels resulting in enhanced fruit set. The number of capsules in primary spike was found to be statistically significant and the data presented in Table 4. Among the genotypes the highest number of capsules per primary spike were recorded in DPC-9 (56.57) and minimum number of capsules were observed in DCS- 
107 (48.87). Among the treatments minimum number capsules per primary spike (48.05) were recorded in control (water spray). Maximum number of capsules (57.23) was recorded in ethrel sprayed at $200 \mathrm{ppm}$ concentration. The increasing concentrations of ethrel treatments were effective in increasing the capsules ranging from 9.8 to 19.0 percent as compared to control. The interaction between treatments and genotypes was found to be significant for number of capsules in primary spike. The maximum number of capsules was recorded in DPC-9 (60.63) when ethrel was sprayed at $200 \mathrm{ppm}$. Minimum number of capsules in primary spike was observed in DCS-107 (41.66) with water spray (control). Ramesh et al., (2002) reported that increase in ethrel concentration increased the number of capsules in castor and was higher at $500 \mathrm{ppm}$. Similar findings were also reported by (Dhedhi et al., 2010 in castor; Mangal et al., 1981 in bittergourd; Saimbhi and Gill, 1988 in summer squash; Vadigeri et al., 2001 in cucumber). The total number of capsules assumes importance as there exists a significant positive association with seed yield (Dorairaj et al., 1973) (Fig. 3).

\section{Seed weight $(\mathrm{g})$}

100 seed weight (g) was significantly influenced by treatments and genotypes and was found to be statistically significant and the data was presented in Table 5. Among the genotypes the DCS-107 (29.80 g) recorded the highest value for 100-seed weight (g) followed by DPC-9 (28.70 g) and M-574 $(28.28 \mathrm{~g})$ recorded lowest value for 100 -seed weight. Ethrel treatments improved the 100seed weight in castor (Mary Varkey et al., 1982 in castor; Sitaram et al., 1989 in cucumber). Among the treatments the highest value for 100-seed weight (g) was recorded in plants sprayed with ethrel at $200 \mathrm{ppm}(30.65$ g) and Lowest value for 100-seed weight (g) was recorded in control (water sprayed) plants
(27.45 g). A significant increase in 100-seed weight from 4 to 10 percent was observed with increasing concentration of ethrel treatments when compared to control. Ethrel treatments improved the 100-seed weight in castor (Mary Varkey et al., 1982 in castor; Sitaram et al., 1989 in cucumber). Increase in seed weight might be due to increased metabolic activity leading to higher translocation of metabolites from source to sinks. Similar results are reported by Arora et al., (1989) in pumpkin. Ethrel caused a high degree of femaleness, increased fruit set in castor and thus, increased the number of seed output and produced heavy seeds (Mary Varkey et al., 1982) (Fig. 4).

\section{Seed yield per plant (g)}

The data on seed yield per plant (g) was found to be statistically significant and presented in Table 6. Among the genotypes the DPC-9 $(90.52 \mathrm{~g})$ recorded the maximum seed yield per plant followed by DCS-107 (85.12 g) and minimum seed yield was recorded in M-574 $(82.86 \mathrm{~g})$. Among the treatments the highest seed yield was recorded in plants sprayed with ethrel at $200 \mathrm{ppm}(88.44 \mathrm{~g})$ followed by ethrel at $150 \mathrm{ppm}(86.96 \mathrm{~g})$ and ethrel at 100 ppm (85.98 g). Lowest seed yield (83.29 g) was recorded in water spray (control) (Fig. 5).

Arora and Pratap (1988) in pumpkin reported that spraying ethrel tends the plants remain physiologically more active to build up sufficient food to developing flowers and fruits and ultimately leading to higher yield. The interaction between treatments and genotypes was found to be significant for seed yield (g) per plant. Maximum seed yield per plant was recorded by ethrel at $200 \mathrm{ppm}$ in DPC-9 (91.60 g) and minimum seed yield was recorded in M-574 (79.95) with water spray (control). Ethrel treatments caused a high degree of femaleness in castor and thus increased the number of seed and ultimately 
the final yield reported by Mary Varkey et al., (1982) in castor.

Ethrel treatments were found to be effective in reducing or suppressing the ISF or male flowers, promoted early flowering and maturity, increased spike length, number of capsules per spike, 100-seed weight and seed yield/plant, resulted in genetic purity. The overall results of the present study revealed that, ethrel treatments are adjudged as the best to suppress the ISF or male flowers in castor, ensure low percentage of selfed seed and ultimately increasing the seed yield and quality of the seed. The present study also established that, ethrel at $200 \mathrm{ppm}$ has a great potential as growth regulator in maintaining pistillateness in hybrid seed production plots, thereby increasing genetic purity of hybrid seed.

\section{References}

Abeles, F. B., P.W, Morgan and M. E, Saltveit Jr. 1992. Ethylene in Plant Biology, $2^{\text {nd }}$ ed. Academic Press, Inc. San Diego, California.

Ankineedu, G and Rao, N. G. P. 1973. Development of pistillate castor. Indian Journal of Genetics and Plant Breeding 33 (3): 416-422.

Arora, S. R., Vashistha, R. N and Pratap, P. S. 1989. Effect of plant growth regulators on growth, flowering and yield of pumpkins (Cucurbita moschata L.). Research and development Reporter 6 (1): 31-34.

Arora, S. K. and Pratap, P. S.1988. Effect of plant growth regulators on vegetative growth, flowering and fruit yield in pumpkin (Cucurbita moschata). Haryana Agricultural University Journal of Research, 28 (4): 284-290.

Cooke, A. R. and D. 1. Randall. 1968. 2Haioethanephosphonic acids as ethylene releasing agents for the induction of flowering in pineapple. Nature 218: 974-975.

Darairaj, M. S., Kondasami, M., Palaniswami, S and Varisai Muhammad, S. 1973. Correlation studies in Ricinus communis L. within inbreds and hybrids. Madras Agricultural Journal. 60 (9-12): 14811485.

Dhedhi, K. K., Dangaria, C.J., Ghelani, Y.H and Joshi, H.J. 2010. Effect of chemicals on sex expression, growth and yield quality of pistillate parent during castor hybrid (GCH 6) seed production. Research on Crops. 11(3): 749-752.

Gopala Krishna Murthy K, Reddy A V V, Lakshmamma $\mathrm{P}$ and Nageswara Rao T. 2003. Manipulation of sex expression in castor (Ricinus communis L.). by chemical treatments. Journal of Oilseeds Research 20 (2): 113-115.

Karchi, Z and Govers Anneke. 1972. Effects of Ethephon on vegetative and flowering behavior in cucumber (Cucumis sativus L.). Journal of American Society Horticulture Science 97(3): 357-360.

Lavanya, C. 2002. Sensitivity of sex expression and sex variation in castor (Ricinus communis L.) to environmental changes. Indian journal of genetics and plant breeding. 62 (3): 232-237.

Mangal, J. L., Pandita, M. L and Singh, G. R. 1981. Effect of various chemicals on growth, flowering and yield of bitter gourd. Indian Journal of Agricultural Research. 15: 185-188.

Mary Varkey, Nigam, R. K and Reuhen, D. E. 1982. Variation in number and length of panicle of castor (Ricinus communis L.) with Chloroflurenol, Ethephon and NIA. Indian Journal of Agricultural Research 16(4): 244-250.

Mitchell, W. D and Mittwer, S. H. 1962. Chemical regulation, sex expression and vegetative growth in Cucumis sativus $\mathrm{L}$. 
Horticulture Sciences, 136: 880-881.

Morgan, P. W. 1969. Stimulation of ethylene evolution and abscission in cotton by 2 chloroethanephosphonic acid. Plant Physiol. 44:337-341.

Ogunniyi, D.S. 2006. Castor Oil: A vital industrial raw material. Bio-resource Technology, 97: 1086-1091.

Ramesh, T., Reddy, D. V. V., Venkat Reddy, T and Durga Prasad, M. M. K. 2000. Effect of ethrel on sex expression and yield of castor (Ricinus communis L.). Journal of Oilseeds Research 17(2): 279-281.

Rudich, J. J., Harley, A. H and Kedar, N. (1972). Ethylene evolution from cucumber plants as related to sex expression. Plant physiology. 49: 99899.

Saimbhi, M. S. and Gill, B. S. 1988. Effect of plant growth regulators on sex expression and yield in summer squash (Cucurbita pepo L.). Journal of Research, Punjab Agricultural University, 25 (1): 49-52.

Shantappa Tirakannanavar Shekhargouda, M., Merwade, M. N., Dharmatti, P. R and Ravinder Mulge. 2006. Sex expression, fruit yield and seed yield in bittergourd (Momordica charantia L.) as affected by plant growth regulators and stages of spray. Journal of Asian Horticulture. 2(1/1): 104-109.

Shiffris, O. 1960. Conventional and unconventional systems controlling sex variations in Ricinus. Journal of genetics 57: 361-388.

Sidhu, A. S., Pandita, M. L. and Hooda, R. S. 1982. Effect of growth regulators on growth, flowering, yield and quality of muskmelon. Haryana Agricultural University Research Journal, 12 (2): 231-235.

Sitaram, Habib, A. F and Kulakarni, G. N. 1989. Effect of growth regulators on seed production and quality in hybrid cucumber (Cucumis sativus L.). Seed Research 17(1): 6-10.

Sitaram, Habib, A. F. and Rudraradhya, M. 1988. Effect of plant growth regulators and dates of sowing on sex expression with special reference to seed production in Cucumis sativus L. variety pickling Lam. Seeds and Farms, 14 (1-3): 20-24

Vadigeri, B. G., Madalageri, B. B and Sheelavantar, M. N. 2001. Effect of ethrel and gibberellic acid on yield and quality of two cucumber varieties. Karnataka Journal of Agricultural Sciences, 14(3): 727-730.

Warner, H. L. and A. C. Leopold. 1969. Ethylene evolution fkom 2-chloroethylphosphonic acid. Plant Physiol. 44: 156-1 58.

Zimmerman, L. H and Smith, J.D. 1966. Production of $\mathrm{f} 1$ seed in castor beans by use of sex genes sensitive to environment. Crop Science, 6: 406-409.

\section{How to cite this article:}

Vema, P. and Narender Reddy, S. 2017. Role of Ethrel in Manipulation of Sex Expression in Pistillate and Monoecious Lines of Castor (Ricinus communis L.) at Different Concentrations. Int.J.Curr.Microbiol.App.Sci. 6(11): 1637-1646. doi: https://doi.org/10.20546/ijcmas.2017.611.196 